\title{
Efficacy of Dissolved Ozone against Staphylococcus aureus and Bacillus cereus Microorganism
}

\author{
Syarifa Fitria', Muhammad Abu Bakar Sidik² , Zolkafle Buntat ${ }^{3}$, Zainuddin Nawawi²*, \\ Muhammad Irfan Jambak², Nur Nabilah Kamarudin³, Fatin Nabilah Musa ${ }^{3}$ \\ 1 Graduate School of Environmental Science, University of Sriwijaya, Palembang, South Sumatra 30128, \\ Indonesia \\ 2 Department of Electrical Engineering, Faculty of Engineering, Sriwijaya University, Ogan Ilir, South Sumatera, \\ Indonesia \\ 3 Institute of High Voltage and High Current, Faculty of Electrical Engineering, Universiti Teknologi Malaysia, \\ 81310, Skudai, Johor, Malaysia \\ * Corresponding author's e-mail: nawawi_z@yahoo.com
}

\begin{abstract}
Ozone is a robust antimicrobial agent with numerous potential applications in the industry. Ozone, in either gaseous or aqueous phases is effective against the majority of microorganisms. Relatively low concentrations of ozone and short contact time are sufficient to inactivate bacteria and microorganism. This project investigated the efficacy of dissolved ozone against food-related microorganism. The ozone system was evaluated using the microbial effects on Staphylococcus aureus, and Bacillus cereus and its clinical efficacy against ORP level for disinfection was determined. The results showed that $100 \%$ of $S$. aureus and B. cereus were eliminated by the dissolved ozone in tap water. In conclusion, the dissolved ozone has great efficacy, lower cost and shorter disinfection cycle. Thus, this low temperature, ozone-based disinfection is a green technique and is regarded as one of the most promising disinfection methods.
\end{abstract}

Keywords: dissolved ozone; bacteria; disinfection

\section{INTRODUCTION}

Foodborne diseases that result from the food spoilage or contaminated food, pathogenic bacteria, viruses, or parasites that contaminate food, are a major concern worldwide. In this context, food-related microorganisms, Staphylococcus aureus (S.aureus), and Baccilus cereus (B. Cereus) are the main microorganisms related to the food safety in terms of frequency and seriousness of the disease (Umar et al., 2013). The bacteria cause two types of gastrointestinal disease, the diarrheal and the emetic syndromes, which are caused by very different types of toxins (Ehling-Schulz et al., 2004). Moreover, the spread of the bacteria is caused by improper disinfection of hand wash.
Over the past few decades, numerous studies for inactivation of various pathogens and microorganisms by various disinfecting agents, including ozone, chlorine dioxide, photocatalytic reaction, free and combined chlorine and short-wavelength UV light have been conducted (Cho et al., 2010; Li, et al., 2011; Van Haute, et al., 2013; Huda, et al., 2019). The primary focus of most studies was providing the information on the disinfectant doses and contact times required to effectively control pathogens. However, the mechanisms of microbial inactivation are relatively poor established (Dodd, 2012).

Among those methods, ozone showed promising results with chemical-free and easy procedure. Ozone is known as a powerful oxidant the disinfection potential of which is widely used in the food industry, medicine and dentistry and 
wastewater treatment (Kim et al., 1999; Seidler et al., 2008; Tango and Gagnon, 2003; Khadre, et al., 2001; Kumar, et al., 2009; Jurczyk, et al., 2019). Ozone is potentially useful in decreasing the microbial load, the level of toxic organic compounds, the chemical oxygen demand, and the biological oxygen demand in the environment (Azarpazhooh and Limeback, 2008).

Ozone, is commonly dissolved into water for water treatment, or for water to carry ozone for disinfection and sterilization. In fact, many of the ozone applications require it to be dissolved into water. As ozone is partially soluble into water, it is possible to dissolve ozone, but the process require the proper equipment to be more efficient. The solubility of ozone into water is based on water temperature, ozone concentration, and water pressure. The process of dissolving ozone in water is optimized by maximizing the surface area between the gas and the water. This is commonly done by using bubble diffusers, venturi injectors and turbine mixers (Hassan and Hawkyard, 2007).

However, ozone is relatively unstable in aqueous solutions. It decomposes continuously, but slowly. The half-life of ozone in distilled water at $20^{\circ} \mathrm{C}$ is generally considered to be 20 to 30 min (Mendes et al., 2007). Therefore, ozone must be generated and used straight away in the disinfection process.

In order to measure the efficiency of the dissolved ozone, Oxidation reduction potential (ORP), electrochemical cell and "Indigo" test can be used. The ORP reacts to any oxidizing influences in the water. ORP is simple, rugged and inexpensive, offering many advantages to realtime monitoring and recording of water disinfection potential, a critical water quality parameter. An ORP probe attached to a meter is placed in the water sample, giving the ORP readout in $\mathrm{mV}$ (Silindir and Ozer, 2009). This method has also been used to check the antibacterial potential of the ozonated water (Fitria et al., 2019).

In this paper, the system investigates the efficacy of dissolved ozone in tap water against $S$. aureus and B. cereus microorganisms. The ozone utilizes low temperature with high sensitivity. Ozone disinfection is carried out through oxidation, a process that destroys the organic and inorganic matter. In this process, a generator is used to convert oxygen to ozone, as a 6 to 12 percent concentration of ozone continuously flows through the chamber. The ozone will dissolve into tap water and the ORP level of 500 to $700 \mathrm{mV}$ are recorded to observe the dissolved ozone reaction to the microorganism.

\section{MATERIAL AND METHODOLOGY}

\section{Ozone - based system}

The experimental setup of the system is as shown in Figure 1. The ozone is produced using a generator to be supplied to the tap water in the tank. Then, the ozone and water were mixed in the mixer tank through a venturi injector and static mixer until it reached the required ORP value as well as $\mathrm{pH}$ value to be analysed. The utilization and handling of ozone should be done safely. Any excess ozone was reverted back to normal oxygen using an ozone destructor making it virtually, non pollutant.

The system is fully automated controlled using the Arduino software (IDE). The Arduino is an easy-to-use hardware and software. Arduino also provides a simple and a clear programming environment for implementations. The $\mathrm{C}$ language used in the development were compiled using the Arduino software (IDE). The entire component such as relay, buzzer, LED, water sensor and ORP meter adapter were connected to the controller box, as shown in Figure 1.

The operation of the ozone-based system is shown in Figure 2. The process control of ozonebased system started when the system is ON, the tank is filled up with 25 liters of tap water. Meanwhile, the water sensor will read the level of water in the tap water tank. If the water level is low, then the buzzer is turned ' $\mathrm{ON}$ ' to start the ozonation process. Afterwards, the water was pumped through an ozone injector. In this project, the venturi injector was used as a method of an ozone injection. The venturi injector is a crucial part to maximize the percentage of ozone transfer into the tap water.

Next, the ozonated water flowed through a static mixer before it was automatically pumped into the contact mixer tank. During this process, the ozone gas was mixed with tap water to dissolve into tap water, thus allowing the water pressure to be maintained. The ORP meter probe from Horiba U-50 series is used to show the ORP reading in $\mathrm{mV}$. The sample of ozonated water that had been set having the value of ORP reading of $500 \mathrm{mV}, 550 \mathrm{mV}, 600 \mathrm{mV}, 650 \mathrm{mV}$ and $700 \mathrm{mV}$ were taken. Each water sample with different 


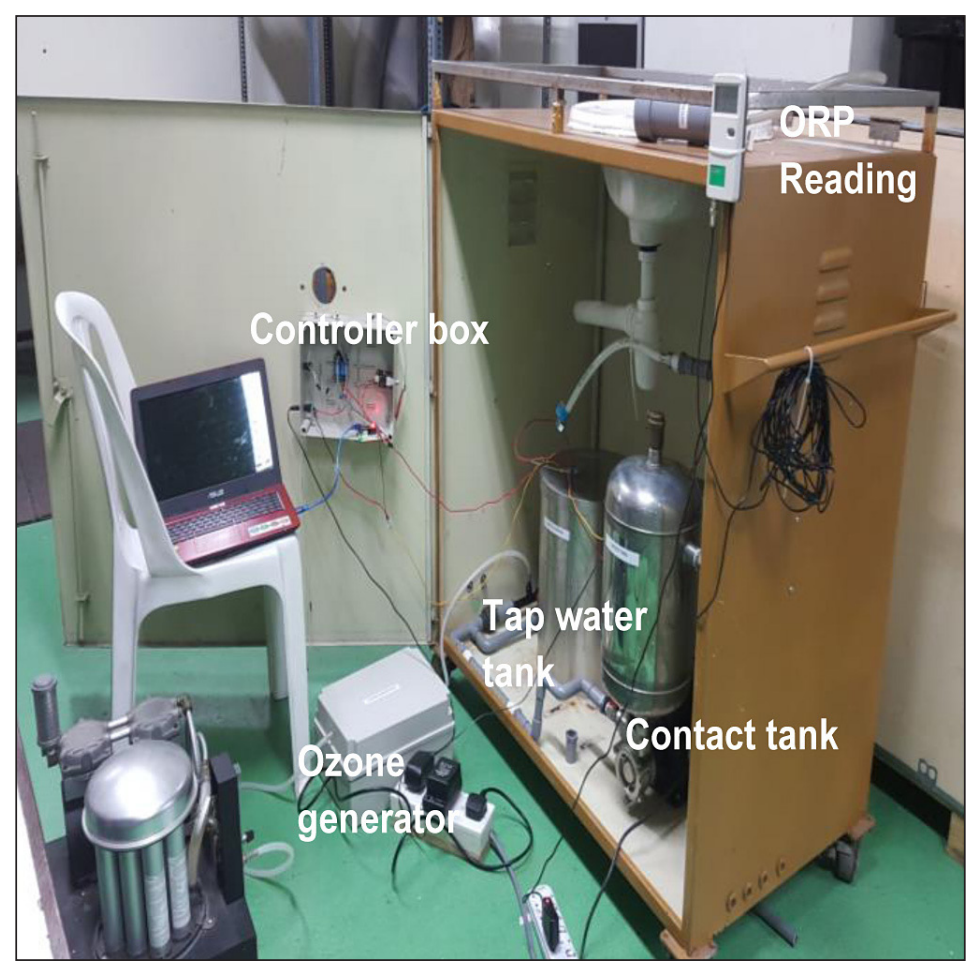

Figure 1. Experimental setup

ORP level was then mixed with cultured bacterial liquid sample to observe their efficacy in killing the bacteria. The process was repeated for another sample of cultured bacterial liquid.

\section{Bacterial Test}

The bacterial strains were diluted with a serial dilution method to obtain a $1 \times 10^{-6}$ dilution. In order to study the efficacy of dissolved ozone in killing the selected bacteria, $0.1 \mathrm{ml}$ of bacterial liquid of culture was mixed with $0.9 \mathrm{ml}$ of ozonated water into an Eppendorf tube follow the level of ORP reading which has been set from $500 \mathrm{mV}$ to $700 \mathrm{mV}$. The controlled tap water suspension was constituted by $0.1 \mathrm{ml}$ for each type of bacteria and similar to mixed with $0.9 \mathrm{ml}$ tap water. The sample was spread onto the agar plate by using a pipette tip. Afterwards, the sample was incubated in an incubator chamber at $30^{\circ} \mathrm{C}$. Next, after growing for $24 \mathrm{~h}$, the number of colonies in each agar plate was calculated using Eq. (1).

$$
\text { Killing rate }(\%)=
$$

$\underline{\text { control colony-tested colony number }}$

control colony number

Eq. (1) Killing rate for microorganism

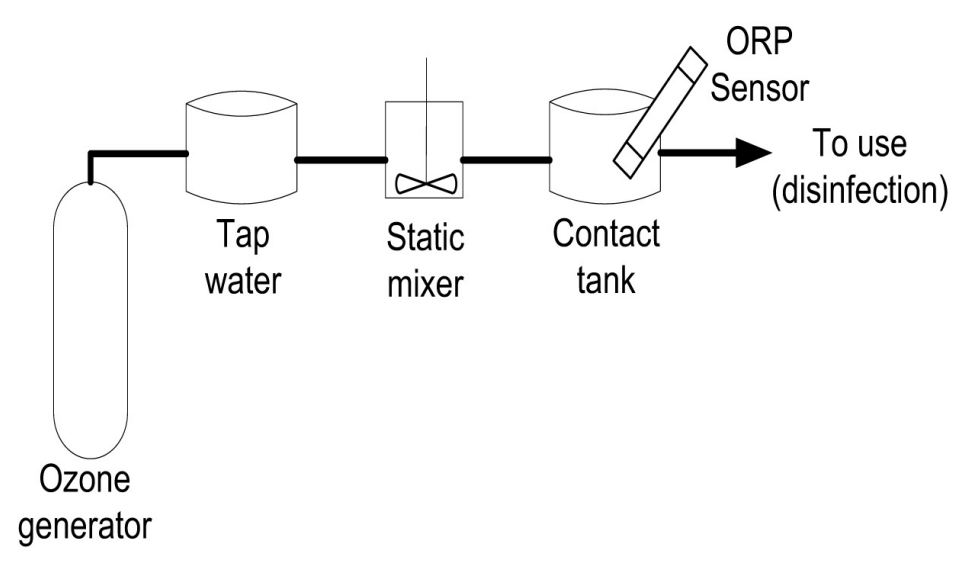

Figure 2. Process of the ozone-based system 


\section{RESULTS AND DISCUSSION}

The efficacy of ozonated tap water with different level of ORP reading $(500,550,600$, 650 , and $700 \mathrm{mV}$ ) in killing the bacteria in tap water was analysed through exposure of the microorganism of S.aureus, and B. Cereus to the dissolved ozone in tap water (ozonated tap water). An analysis was conducted to observe what ORP level is optimum for the dissolved ozone to inhibit the microorganisms effectively.

Table 1. Bacterial test on the controlled and ozonated tap water

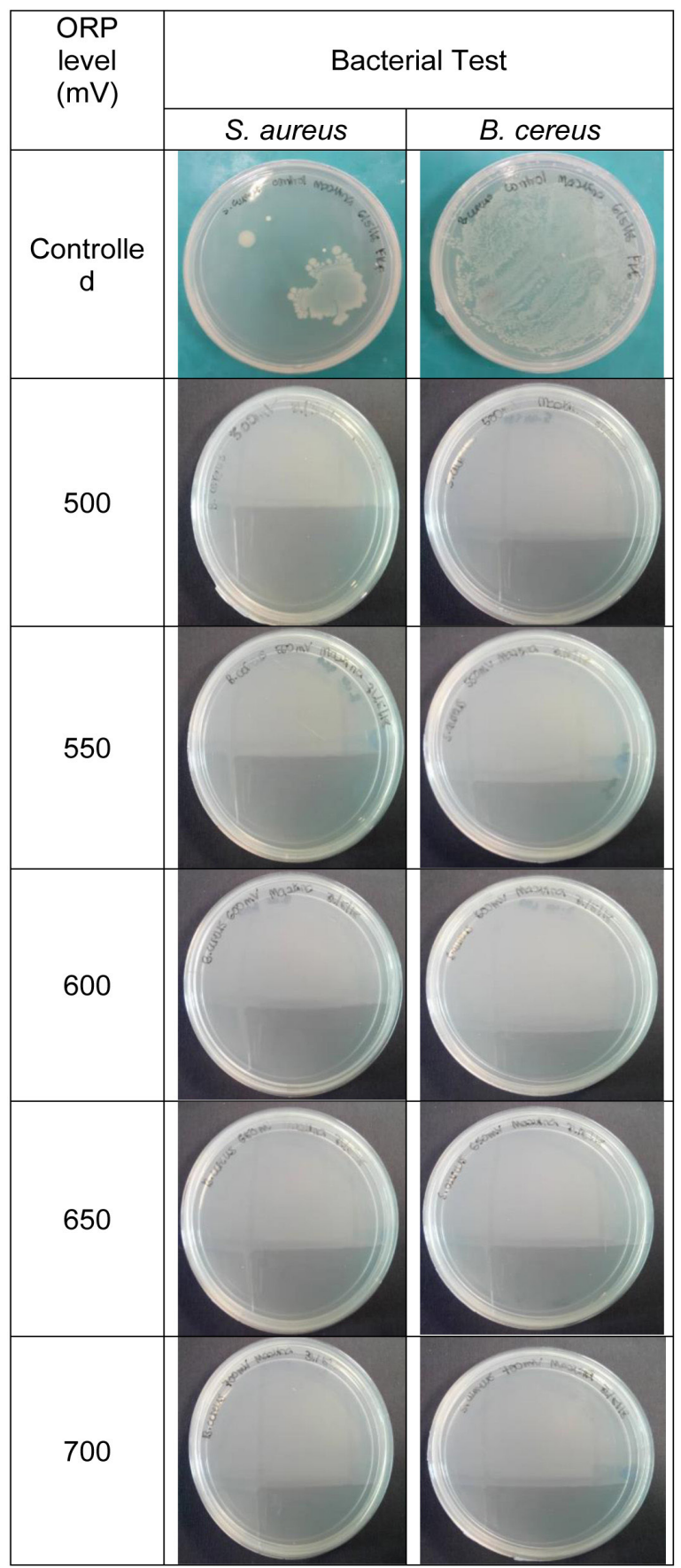

Table 1 show the result of the samples after incubation.

This test study was carried out to determine whether the ozonated tap water with different level of ORP reading has effective disinfecting action on the deposited bacteria which are $B$. cereus and $S$. aureus after being sprayed on the agar surfaces in Petri dishes. As can be seen from Table 1, the $B$. cereus and $S$. aureus bacteria can be clearly observed on the surface of the agar sample of untreated tap water. It means that the $B$. cereus bacteria and $S$. aureus bacteria can grow well in this type of environment.

The first sample of dissolved ozone with ORP reading of $500 \mathrm{mV}$ mixed with agar surfaces in petri dishes showed the absence of both $B$. cereus and $S$. aureus. Similarly, the sample applied with 550, 600, 650 and $700 \mathrm{mV}$ showed clear surfaces in petri dishes indicating that the bacteria were completely killed. There are clearly no signs of colony-form or any bacteria growing in petri dishes mixed with the ozonated tap water samples for both types of bacteria in every ORP level set as above.

The bacteria were counted and compared with the ORP level and controlled condition respectively, using colony-forming unit to calculate the killing rate. The colonial test of the controlled sample showed the existence of colony-forming in both samples of $B$. cereus and $S$. aureus bacteria. Conversely, the sample applied with ozonated tap water showed no colony-forming of both bacteria sample at any level of ORP. The result of the killing rate of the samples is as shown in Figure 3.

In this study, it was shown that the ozonated water with ORP reading above $500 \mathrm{mV}$ has strong in vitro antibacterial effect against $B$. cereus, and $S$. aureus. From the data shown, the ozonated water $(1 \mathrm{ml})$ was capable to sterilize $100 \%$ of B. cereus, and $100 \%$ of $S$. aureus in 24 hours. This result indicates that ozone disinfection has very powerful antimicrobial effect against gram negative and positive microorganisms, which was confirmed by the digital microscope view of ozonated water.

The results indicate that the ORP value of 500 to $700 \mathrm{mV}$ shows an excellent effect in killing all the bacteria. However, in order to achieved promising and excellent result in all applications, $700 \mathrm{mV}$ is set as the optimum ORP level of disinfection. It is believed that at this level, all the bacteria are confirmed killed. 


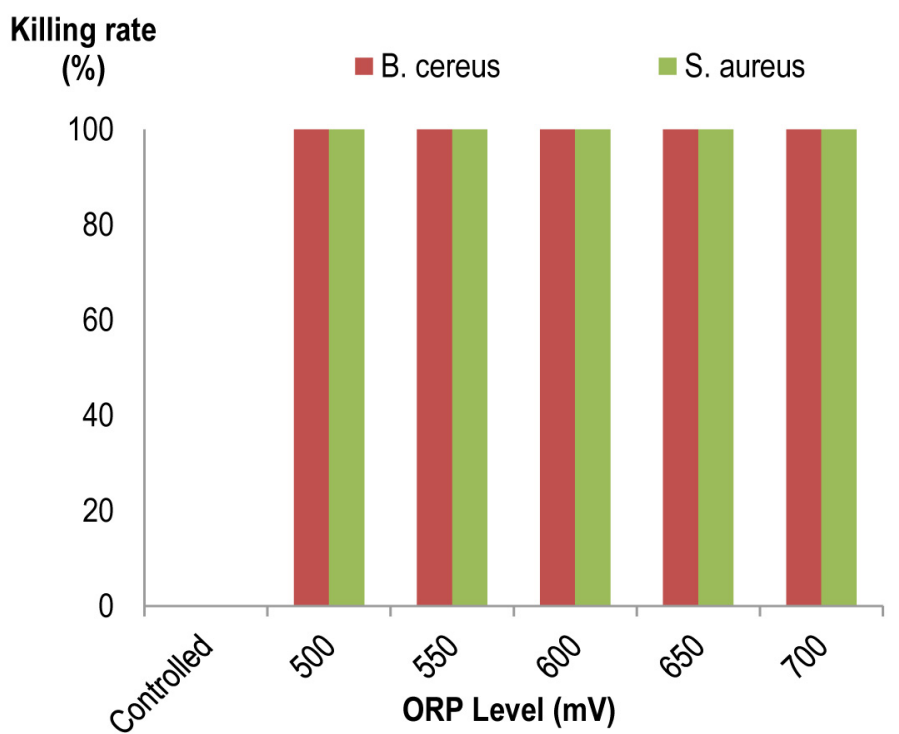

Figure. 3. Killing rate

\section{CONCLUSION}

In conclusion, the dissolved ozone in tap water shows an effective way in removing and simultaneously destroying the microorganisms. The results showed that it can effectively kill $100 \%$ of B. cereus, and $S$. aureus at ORP level as low as $500 \mathrm{mV}$ of dissolved ozone. However, for future industrial applications, the ORP level of $700 \mathrm{mV}$ is recommended as the optimum level for the disinfection. It was proven that dissolved ozone in tap water can be a powerful medium and high efficacy in disinfecting bacteria, which has 6 times the oxidizing power of chlorine and other substances.

\section{Acknowledgment}

This work was supported by the Universitas Sriwijaya- Universiti Teknologi Malaysia, Research Collaboration Grant (R.J130000.7323.4B276).

\section{REFERENCES}

1. Azarpazhooh, A. and Limeback, H., 2008. The application of ozone in dentistry: a systematic review of literature. Journal of dentistry, 36(2), 104-116.

2. Cho, M., Kim, J., Kim, J.Y., Yoon, J. and Kim, J.H., 2010. Mechanisms of Escherichia coli inactivation by several disinfectants. Water Research, 44(11), 3410-3418.

3. Dodd, M.C., 2012. Potential impacts of disinfection processes on elimination and deactivation of antibiotic resistance genes during water and wastewater treatment. Journal of Environmental Monitoring, 14(7), 1754-1771.

4. Ehling- Schulz, M., Fricker, M. and Scherer, S., 2004. Bacillus cereus, the causative agent of an emetic type of food- borne illness. Molecular nutrition \& food research, 48(7), 479-487.

5. Fitria, S., Buntat, Z., Nawawi, Z., Abu, M., Sidik, B., Jambak, M. I., and Yuniarti, D. 2019. Antibacterial Potency of Ozonated Water against Escherichia coli, Journal of Pure and Applied Microbiology. 13(March), 637-641.

6. Hassan, M. M., \& Hawkyard, C. J. (2007). Decolorisation of effluent with ozone and re-use of spent dyebath. Environmental Aspects of Textile Dyeing, 149-190.

7. Huda, A., Suman, P.H., Torquato, L.D.M., Silva, B.F., Handoko, C.T., Gulo, F., Zanoni, M.V.B., Orlandi, M.O. (2019). Visible light-driven photoelectrocatalytic degradation of acid yellow 17 using Sn3O4 flower-like thin films supported on Ti substrate ( $\mathrm{Sn} 3 \mathrm{O} 4 / \mathrm{TiO} 2 / \mathrm{Ti})$. Journal of Photochemistry and Photobiology A: Chemistry. 376, 196-205.

8. Jurczyk, Ł., Koc-Jurczyk, J. and Balawejder, M. 2019. Quantitative dynamics of chosen bacteria phylla in wastewater treatment plants excess sludge after ozone treatment. Journal of Ecological Engineering, 20(3), 204-213.

9. Khadre, M.A., Yousef, A.E. and Kim, J.G., 2001. Microbiological aspects of ozone applications in food: a review. Journal of food science, 66(9), $1242-1252$.

10. Kumar, T.K., Murali, H.S. and Batra, H.V., 2009. Simultaneous detection of pathogenic B. cereus, S. aureus and L. monocytogenes by multiplex PCR. 
Indian journal of microbiology, 49(3), 283-289.

11. Kim, J.G., Yousef, A.E. and Dave, S., 1999. Application of ozone for enhancing the microbiological safety and quality of foods: a review. Journal of food protection, 62(9), 1071-1087.

12. Li, H., Zhu, X. and Ni, J., 2011. Comparison of electrochemical method with ozonation, chlorination and monochloramination in drinking water disinfection. Electrochimica Acta, 56(27), 9789-9796.

13. Mendes, G. C., Brandao, T. R., \& Silva, C. L. (2007). Ethylene oxide disinfection of medical devices: a review. American journal of infection control, 35(9), 574-581.

14. Seidler, V., Linetskiy, I., Hubálková, H., Stankova, H., Smucler, R. and Mazánek, J., 2008. Ozone and its usage in general medicine and dentistry. A review article. Prague Med Rep, 109(1), 5-13.
15. Silindir, M., \& Ozer, A.Y. 2009. Disinfection methods and the comparison of e-beam disinfection with gamma radiation disinfection. Fabad J Pharm Sci, 34(34), 43-53.

16. Tango, M.S. and Gagnon, G.A., 2003. Impact of ozonation on water quality in marine recirculation systems. Aquacultural Engineering, 29(3-4), 125-137.

17. Umar, M., Roddick, F., Fan, L. and Aziz, H.A., 2013. Application of ozone for the removal of bisphenol A from water and wastewater - a review. Chemosphere, 90(8), 2197-2207.

18. Van Haute, S., Sampers, I., Holvoet, K. and Uyttendaele, M., 2013. Physicochemical quality and chemical safety of chlorine as a reconditioning agent and wash water disinfectant for fresh-cut lettuce washing. Applied and Environmental Microbiology, 79(9), 2850-2861. 